\title{
GENETIC SIMILARITY BETWEEN STAPHYLOCOCCUS SP ISOLATED FROM HUMAN AND HOSPITAL SETTINGS, AND SUSCEPTIBILITY TO DIFFERENT ANTIMICROBIALS
}

\author{
Telma Luciana Trovó Fabiano ${ }^{1}$; Bruna Helena Pinheiro de Ávila² ${ }^{2}$ Cleusa Cascaes Dias² ${ }^{2}$ Renato Pariz Maluta ; \\ Fernando Antonio de Ávila ${ }^{1 *}$
}

${ }^{1}$ Programa de Pós-Graduação em Microbiologia Agropecuária, Universidade Estadual Paulista, Jaboticabal, SP, Brasil; ${ }^{2}$ Faculdade de Medicina, Centro Universitário Barão de Mauá, Ribeirão Preto, SP, Brasil

Submitted: October 30, 2007; Returned to authors for corrections: February 12, 2008; Approved: November 02, 2008.

\begin{abstract}
One hundred and forty-three samples from human hands and hospital beds were collected at a teaching hospital in the city of Ribeirão Preto/SP by swabs, and placed in BHI broth. Following a $24 \mathrm{~h}$ incubation period at $37^{\circ} \mathrm{C}$, they were seeded on Petri dishes containing Agar "Staphylococcus Medium 110". Colonies typical of the genus Staphylococcus were collected and stored at $4^{\circ} \mathrm{C}$ until tested for catalase, mannitol, hemolysis, DNAse and coagulase. Strains were analyzed by RAPD-PCR to verify their similarity, and tested for sensitivity to ten different antibiotics. From the ninety-two isolated strains, $67(72,8 \%)$ were coagulase- negative and 25 $(27,2 \%)$ coagulase-positive. Similarity analysis showed a great heterogeneity among strains, but some presented $100 \%$ similarity. Resistance to oxacilin was encountered in $39(42 \%)$ of the strains. Two coagulasenegative strains were resistant to vancomycin, and eleven (12\%) were considered multiresistant. Measures such as hand disinfection of the staff and hospital beds and rationalization of antibiotic use could contribute to decrease pathogen transmission and selection pressure, diminishing the frequency and lethality of nosocomial infections.
\end{abstract}

Key words: Similarity, RAPD-PCR, multiresistance, Staphylococcus.

\section{INTRODUCTION}

Despite the advances obtained by Medicine over the last years, infirmities decurring from hospital infecting conditions keep causing a significant number of victims over the world. They are mainly transmitted by etiological agents present in the hospital's environment (31).

Pathogens of the Staphylococcus genus presently represent one of the biggest challenges to world public health (3). The genus is composed of 37 species, 17 of which can be isolated from human samples (15). Staphylococcus epidermidis and Staphylococcus aureus are the main colonizers of skin, nasopharynx and gastrointestinal tract; the latter being the major agents causing hospital infections (17), varying from cutaneous to systemic (21).
Indiscriminate antimicrobial use has lead to an increase of $S$. aureus strains resistant to methycillin (MRSA). Since such strains are also considered to be resistant to all beta-lactamic antimicrobials (6), the therapeutic arsenal useful to fight these pathogens has been curtailed. In addition theses strains, having become endemic in many hospitals, have led to increased use of vancomycin that has, in many cases become the only alternative to fight MRSA infections; this procedure, has however favored the selection of Enterococcus and of S. aureus strains resistant to that antibiotic $(12,13)$. Over the last years, several reports on nosocomial resistant phenotypes have appeared; they include VISA (vancomicyn-intermediate $S$. aureus) and VICoNS (vancomicyn-intermediate coagulasenegative Staphylococcus), as well as VRSA (vancomicynresistent $S$. aureus) strains $(8,26)$, first described in Japan (13).

*Corresponding Author. Mailing address: Faculdade de Ciências Agrárias e Veterinárias, Departamento de Patologia Veterinária, Laboratório de Microbiologia, Universidade Estadual Paulista, Via de Acesso Prof. Paulo Donato Castellane, s/n. 14884-900, Jaboticabal, SP, Brasil. Phone: (+5516) 3209-2652, Fax: (+5516) 3202-4275. E-mail: favila@fcav.unesp.br

* Financially supported by: CAPES, CNPq and FAPESP. 
The efficiency of hand hygienization can predict MRSA prevalence (10), and hygiene measures can decrease MRSA, reducing the need to use antibiotics and treatment cost (18). Workers in transient- or persistently colonized health sectors can transmit MRSA to patients (1); hospital beds may constitute an additional risk factor for such infections $(7,9)$.

A variant of conventional PCR is random amplified polymorphic DNA (RAPD-PCR, or in short, AP-PCR), a technique that utilizes arbitrary primers, and has been much applied in investigations on intra-hospital out breaks like epidemics caused by $S$. aureus (5) and coagulase-negative staphylococci (4).

The integration of molecular typing with conventional methods has increased the efficacy of epidemiological hospital applications, and led to a reduced incidence of nosocomial infections (32).

The present work was therefore aimed at the isolation and identification of Staphylococcus sp strains from human hands and beds in a teaching hospital in the city of Ribeirão Preto/SP, and their characterization by the RAPD-PCR technique to verify the extent of their similarities and sensitivity to different antibiotics.

\section{MATERIALAND METHODS}

\section{Isolation and identification of Staphylococcus sp}

The study was performed at the Santa Casa de Misericórdia Hospital of Ribeirão Preto/SP, and was authorized by its ethics committee; all participants signed a term of consent for the collection of clinical specimens; results obtained were passed on to the head of the Hospital's Maternitiy Service. Samples were collected at the Hospital'sGynecology and Obstetrics Sectors, between August, 24/2005 and August, 28/2006. Their statistical significance was calculated by the following formula: $n_{0}=Z^{2} \times p(1-p) / d^{2}$ where $n_{0}=$ size of the population studied; $p$ $=$ proportion of samples showing the presence of microorganisms; $\mathrm{d}=$ precision desired of the proportion estimates $(0,05)$, and $\mathrm{Z}=$ percent of normal distribution at $\mathrm{a}=$ 0,05 . A total of 143 samples were collected by sterile swabs, five from the right hand of students, 26 from the right hand of male nurses, four from the right hand of physicians, 59 from the right hand of interned patients and 49 from bed tops, placed in test tubes containing $1,0 \mathrm{~mL}$ of brain and heart infusion broth BHI (Oxoid, Basingstoke, UK), incubated at $37^{\circ} \mathrm{C}$ for $24 \mathrm{~h}$, and seeded on Petri dishes containing agar Staphylococcus Médium 110 (Difco, Sparks, USA), and reincubated at $37^{\circ} \mathrm{C}$ for $24 \mathrm{~h}$. Colonies were then macroscopically examined for morphology, and pigment production. Swabs from suspected colonies were Gramstained for morphotinctorial confirmation and respectively, for the evaluation of catalase and sheep blood hemolysis in agar, mannitol fermentation, coagulase production and DNAse (16). Strains characterized as being Staphylococcus coagulase- positive (CoPS) and Staphylococcus coagulase-negative (CoNS), were seeded in tubes containing $2 \mathrm{~mL}$ of agar BHI, incubated at $37^{\circ} \mathrm{C}$ for $24 \mathrm{~h}$ and stored at $4^{\circ} \mathrm{C}$. The -square test $\left(\chi^{2}\right)$ was used to study the correlation frequency between coagulase-positive, and coagulase-negative strains of Staphylococcus. A value of $P<0.05$ was considered to be statistically significant (26).

\section{Antimicrobial sensitivity}

Coagulase-positive and negative Staphylococcus strains were isolated, and tested by disc-diffusion, for sensitivity to the following antimicrobials (25): oxacillin $(10 \mu \mathrm{g})$, cephazolin $(30 \mu \mathrm{g})$, ciprofloxacin $(5 \mu \mathrm{g})$, clavulanic acid +amoxicillin (30 $\mu \mathrm{g})$, vancomycin $(30 \mu \mathrm{g})$, azitromycin $(15 \mu \mathrm{g})$, clindamycin (2 $\mu \mathrm{g})$, amoxicillin $(10 \mu \mathrm{g})$, enrofloxacin $(5 \mu \mathrm{g})$ and ampicillin (10 $\mu \mathrm{g})$. Additionally, the test of minimal inhibitory concentration (MIC) was performed by macro dilution in a vancomycin broth, on strains shown to be insensitive to that antimicrobial by the disc-diffusion test (24). Results of MIC and disc-diffusion were compared by a guide chart. (6). These antimicrobials have been reported for the treatment of staphylococci infections, in a CLSI document (6). Strains resistant to more than six antimicrobials were considered to be multiresistant (23).

\section{RAPD-PCR}

Genomic DNA extraction was performed according to the recommendations of the GFX Genomic Blood - DNA Purification Kit (GE Healthcare). Concentration and purity of DNA were spectrophotometrically determined at $260 \mathrm{~nm}$ and $280 \mathrm{~nm}$, in a DU-640B apparatus, (Beckman Coulter Inc., Fullerton, CA, USA) and samples stored at $-20^{\circ} \mathrm{C}$ until use.

Molecular typing was made with two Staphylococcus strains, aleatorily chosen among the strains isolated, and tested by RAPD-PCR following recommendations of the Kit of Ready-To-Go/RAPD Analysis Beads (GE Healthcare). Six primers supplied by the Kit (Primer 1: 5' - d[GGTGCGGGAA]3'; Primer 2: 5'-d[GTTTCGCTCC]-3';: Primer 3: 5'd[GTAGACCCGT]-3'; Primer 4: 5' -d[AAGAGCCCGT]-3'; Primer 5: 5'-d[AACGCGCAAC]-3' and Primer 6: 5' d[CCCGTCAGCA]-3') were tested; the one presenting the best amplification that is, highest visibility and ease of discernment banding in a trial of 10 strains (Primer 6), was applied to all CPS and CoNS strains. All procedures utilized sterile water and were analyzed by the thermocycler PTC-100 (MJ Research Inc.), Waltham, MA, USA.

Products were submitted to $2 \%$ agarose gel electrophoresis and stained with ethidium bromide, $(0,5 \mathrm{mg} / \mathrm{mL})$ for $2 \mathrm{~h}$ and 30 min at 150 Volts. The 100pb "Ladder" (GE Healthcare) was utilized as the molecular size standard; PCR products were visualized in an UV transluminator-UV, (Syngene - Cambridge, United Kingdom), and photo documented by a digital camera (Synoptics) and Gene link (Syngene) software. 


\section{Similarity Analysis}

By means of the analysis of bands produced with the aleatory initiator oligonucleotide, a binary matrix of the absence and presence of bands was generated, and the similarity matrix constructed, based on Dice's correlation coefficient and by the method of the mean genetic distances UPGMA (Unweighted Pair Group Method for Arithmetic Averages) using the Freetree program (0.9.1.50 version). Phylogenetic trees of the coagulase positive and coagulase negative strains respectively, were obtained and visualized using the TreeView program (1.30 version)

\section{RESULTS}

Statistical analysis showed, at a significance level $(\mathrm{P}<0,05)$, that isolation frequencies of CoPS and CoNS, respectively, differed. Table 1 shows the number and percentage and Table 2 shows the profile of susceptibility of the CoPS e CoNS strains isolated.

Among all strains of staphylococci examined, $42 \%$ presented a phenotype profile of resistance to oxacillin (meticillin). Two CoNS strains (also resistant to oxacillin) presented resistance to vancomycin (MIC $>32 \mu \mathrm{g} / \mathrm{ml}$ ). According to our results obtained by the sensitivity test, among the 92 strains of Staphylococcus sp isolated, 11 (12\%), were considered multiresistant, and among them, only one did not show a phenotype profile of resistance to oxacillin (Table 3).

Fig. 1 demonstrates the similarity relationships between strains of CoPS in 5 distinct clusters; Fig. 2 shows such similarity between CoNS strains in 8 different clusters.

\section{DISCUSSION}

Human carriers (students, nursing aids, physicians, and patients) showed an isolation frequency of coagulase-positive staphylococci $(40,0 \% ; 19,2 \% ; 25,0 \%$ e $25,4 \%$, respectively), higher than those isolated from bed tops $(4,1 \%)$; this suggests that in the hospital, human colonization is more common than bed colonization, and it seems possible that horizontal transmission between human beings could be the easier one. This is important data, since MRSA has already been isolated from hospital beds $(7,9)$. Nevertheless, the isolation frequency of CoNS from different sources was very similar, showing that perhaps these strains have become adapted to both colonization in humans carriers, as well as in beds.

The similarity phylogram built for CoPS strains, demonstrated the presence of five distinct clusters (A, B, C, D, E). Cluster A was constituted by only one CoPS strain originated from one patient, and presented the biggest genetic distance among all. Clusters B and C were constituted by samples from beds, patients, nursing assistants and the only sample of CoPS originated from physicians. These clusters presented high origin
Table 1. Source, number of samples and results of coagulase production of staphylococci strains isolated from 143 samples of humans and beds at a Medical Teaching Hospital in Ribeirão Preto-SP.

\begin{tabular}{lccccc}
\hline \multirow{2}{*}{ Source } & $\begin{array}{c}\text { N } \mathrm{N}^{\circ} \text {. of } \\
\text { samples }\end{array}$ & \multicolumn{5}{c}{$\begin{array}{c}\text { Coagulase } \\
\text { production }\end{array}$} \\
\cline { 3 - 6 } & & \multicolumn{4}{c}{+} \\
\hline & & $\mathrm{N}^{\mathbf{o}}$. & $\%$ & $\mathrm{~N}^{\mathbf{0}}$. & $\%$ \\
\cline { 3 - 6 } Top of beds & 49 & 2 & 4.1 & 21 & 42.9 \\
Student hands & 5 & 2 & 40.0 & 2 & 40.0 \\
Nurse hands & 26 & 5 & 19.2 & 10 & 38.5 \\
Doctors hands & 4 & 1 & 25.0 & 2 & 50.0 \\
Patients hands & 59 & 15 & 25.4 & 32 & 54.2 \\
\hline TOTAL & $\mathbf{1 4 3}$ & $\mathbf{2 5}$ & 17.5 & $\mathbf{6 7}$ & 46.9 \\
\hline
\end{tabular}

Table 2. Profile of resistance of staphylococci strains isolated from 143 samples of humans and beds at a Medical Teaching Hospital in Ribeirão Preto-SP.

\begin{tabular}{|c|c|c|c|c|}
\hline \multirow[t]{2}{*}{ Antimicrobials } & \multicolumn{2}{|c|}{$\begin{array}{c}\text { Resistant } \\
\text { isolates }\end{array}$} & \multicolumn{2}{|c|}{ Coagulase } \\
\hline & $\mathrm{N}^{\mathrm{o}}$. & $(\%)$ & $+\left(\mathrm{N}^{\mathrm{o}}.\right)$ & $-\left(\mathrm{N}^{\mathrm{o}}.\right)$ \\
\hline Oxacillin & 39 & 42.4 & 11 & 28 \\
\hline Cephazolin & 36 & 39.1 & 10 & 26 \\
\hline Ciprofloxacin & 27 & 29.4 & 7 & 20 \\
\hline Clavulonic ac. + amoxicillin & 14 & 15.2 & 5 & 9 \\
\hline Vancomycin & 2 & 2.2 & - & 2 \\
\hline Azythromycin & 33 & 35.9 & 10 & 23 \\
\hline Clindamycin & 39 & 42.4 & 6 & 33 \\
\hline Amoxicillin & 77 & 83.7 & 15 & 62 \\
\hline Enrofloxacin & 32 & 34.8 & 15 & 17 \\
\hline Ampicillin & 52 & 56.5 & 18 & 34 \\
\hline
\end{tabular}

heterogeneity; however, it is interesting to note in cluster B, that three patient samples presented a $100 \%$ similarity, indicating that there may have occurred horizontal transmission of the same strain between these patients. Cluster D also presented heterogeneity, but the presence of samples originating from patients was more accentuated. Cluster E was the only one presenting student samples (with an $80 \%$ similarity), showing that perhaps CoPS strains colonizing students is more specific.

Due to the genetic distance observed in the majority of strains (only six presented similarity indexes above $70 \%$ in relation to others), it is probable that the CoPS in this study had diverse origins; this contrasts with a study of MRSA made in 
Table 3. Pattern, number of strains and phenotypic antimicrobial resistance among multiresistant Staphylococcus sp strains isolated from humans and tops of hospital beds.

\begin{tabular}{cccc}
\hline Pattern & No. ofstrains & Antimicrobials \\
\hline 7 antimicrobial resistance & 6 & 1 & oxa-cip-azi-cli-amo-em-amp \\
& & 1 & oxa-cip-azi-cli-amo-em-amp \\
& & 1 & oxa-cfz-azi-cli-amo-em-amp \\
& & 1 & cfz-cip-azi-cli-amo-em-amp \\
& & 2 & oxa-cfz-cip-azi-cli-amo-em \\
& 1 & 1 & oxa-cfz-cip-azi-cli-amo-em-van \\
8 antimicrobial resistance & 4 & 4 & oxa-cfz-cip-acm-azi-cli-amo-em-amp \\
9 antimicrobial resistance & &
\end{tabular}

*oxa-oxacillin, cfz-cephazolin, cip-ciprofloxacin, amc-amoxicillin+clavulonic acid, van-vancomycin, azi-azythromycin, cli-clindamycin, amoamoxicillin, em-enrofloxacin, amp-ampicillin.

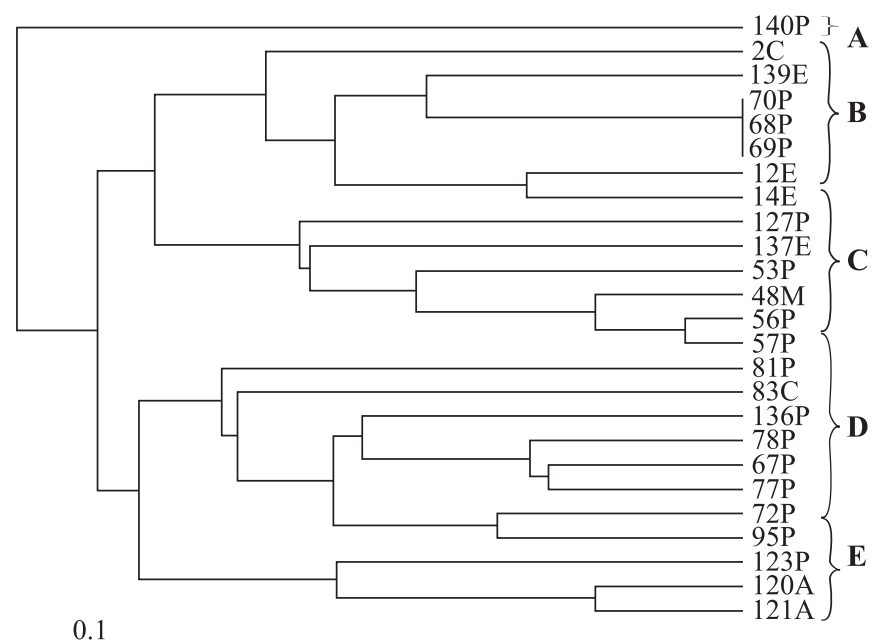

Figure 1. Phylogenetic tree among $25 \mathrm{CoPS}$ strains, constructed by Free Tree "software" and Distance Coefficient (DICE), showing relationships, by the UPGMA method.

Campinas, Brazil (2), reporting that an epidemic strain stayed constant along time.

It is of interest to note that in cluster A (Fig. 2), two strains (116C and 99P), presented $100 \%$ similarity, showing that CoNS transmission between bed top and a patient occurred (although it is not possible to determine its direction). The other clusters, excepting cluster G, presented a large diversity of their origins, That may have been due to constant cross transmission of CoNS strains; another reason that could have generated such high diversity, would be that the CoNS groups are constituted by more than one species, and the differences between them could have produced profiles of differing similarity. Complementing studies will be required to determine pathogenic factors in these CoNS, in order to evidence a possible risk, since in a study performed in the city of Caxias do Sul, Brazil, such factors were found in Staphylococcus epidermidis (23).

Nosocomial infections caused by Staphylococcus sp are frequently life threatening and of difficult treatment (27); those caused by multiple Staphylococcus resistance to antibiotics are growing problems in many health institutions $(14,23)$, becoming capable of interfering with disease treatments, and of potentially affecting curable clinical pictures by restricting the number of available antibiotics. In the present study, the percentage of multiresistant strains $(12 \%)$ was much lower than the percentage of Staphylococcus sp (74\%) in samples from Caxias do Sul (23); however, there isolates were obtained from clinical specimens (blood, catheters) on which selective pressure from antimicrobials could have been much higher.

In our work, isolation frequency of Staphylococcus sp resistant to oxacillin (42\%), was lower than that found in another study developed (22), in a hospital in the city of Uberlândia, Brazil (78\%). Nevertheless, although lower, such level can also cause worry, since oxacillin-resistant microorganisms are considered to be resistant to all $\beta$-lactamic antimicrobials $(6,24)$. The upsurge of Staphylococcus resistant to vancomycin, demonstrating a homogeneous pattern of resistance, may signify a more threatening problem, even though strains with such phenotype profiles are relatively rare $(11,20)$.

CoNS are considered the main agents implicated in infections associated with the use of intravenous catheters (4). In the present study, eight CoNS strains were resistant to vancomycin by the disc diffusion test; among them, only two demonstrated resistance in the MIC test, showing the low sensitivity of vancomycin in the diffusion test. These two strains, resistant to vancomycin presented multiple resistance to various antimicrobials, including oxacillin. These data agree with other reports showing strains simultaneously resistant to vancomycin and various other antimicrobials $(33,34)$. In the State of Rio de Janeiro and in the cities of S. Paulo and Porto Alegre, S. aureus strains resistant to glycopeptides, with intermediary resistance 


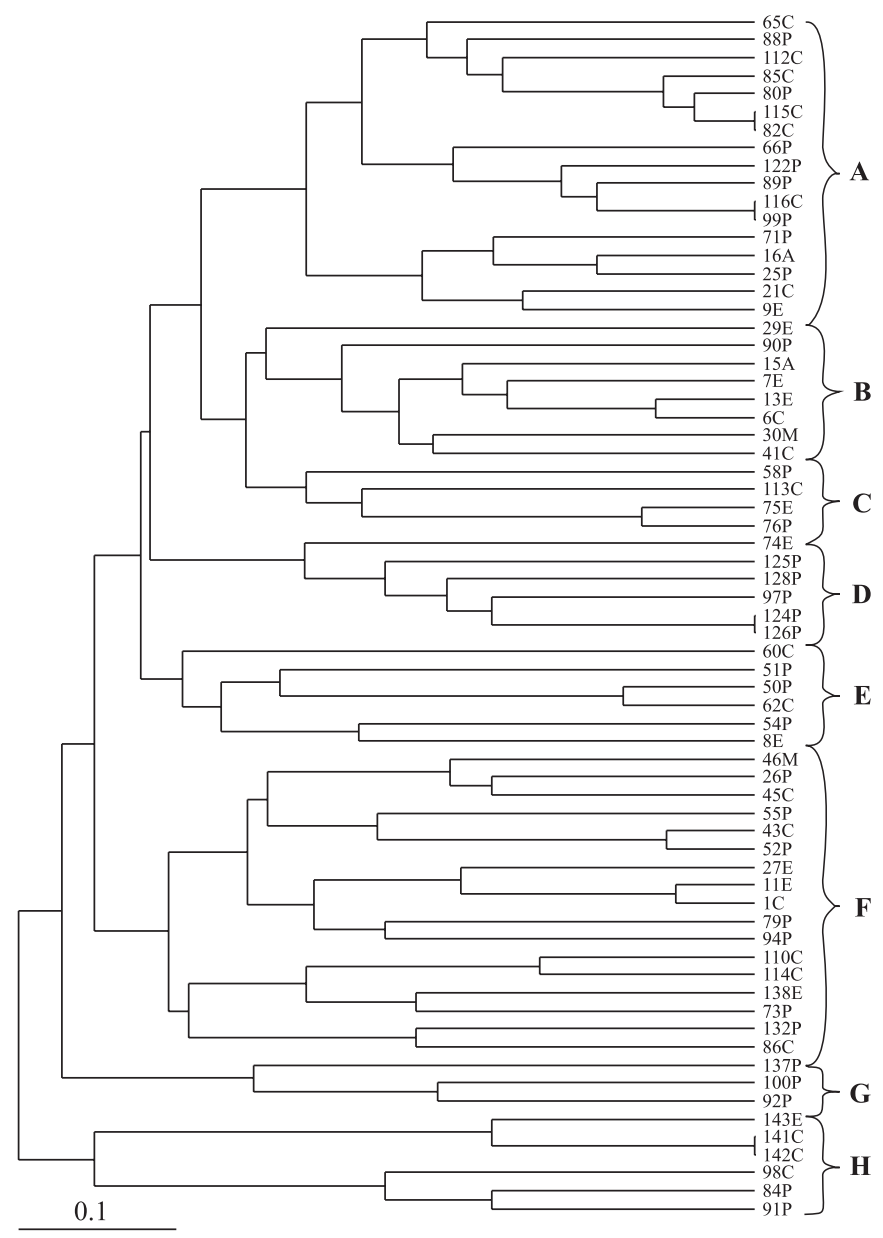

Figure 2. Phylogenetic tree among 67 CoNS strains, constructed by Free Tree "software" and Distance Coefficient (DICE), showing relationships, by the UPGMA method.

to vancomycin have been reported, and also in the city of S. Paulo, Staphylococcus coagulase- negative strains resistant to vancomycin have been found $(19,29,30)$.

Resistance to oxaciliin/meticillin or to vancomycin is an inevitable sequence to the selective pressure exerted by antibiotics. Although the details of the epidemiologic resistance to these drugs in Staphylococcus may change, the primordial forces that direct the phenomenon are similar. Concerning $S$. aureus, the question rather is, not when resistance is going to occur, but how prevalent it will become (28). The present study evidenced that there may have occurred horizontal transmission of CoPS between patient/patient and of CoNS between bed/ bed, patient/patient and bed/patient. Measures of staff hands disinfection and of rationalization of hospital beds and against indiscriminate use of antibiotics can contribute to the lowering of pathogen transmission and of selection pressure, consequently decreasing the frequency and lethality of nosocomial infections.

\section{RESUMO}

\section{Similaridade genética entre estafilococos isolados de humanos e camas hospitalares e resistência à diferentes antimicrobianos}

Foram coletadas 143 amostras de mãos de humanos e camas hospitalares, através de "swabs" no caldo BHI, em um hospital escola da cidade de Ribeirão Preto/SP. As amostras coletadas foram incubadas a $37^{\circ} \mathrm{C}$ por 24 horas e após este período as culturas foram semeadas em placas de Petri contendo agar "Staphylococcus Médium 110". As colônias típicas do gênero Staphylococcus foram colhidas e estocados a $4^{\circ} \mathrm{C}$ até o momento de elaboração das provas de catalase, manitol, hemólise, DNAse e coagulase. As cepas isoladas foram analisadas através da técnica de RAPD-PCR para verificar o grau de similaridade. A sensibilidade das cepas isoladas foi testada frente a 10 diferentes antibióticos. Das 92 cepas de Staphylococcus sp isoladas, 67 $(72,8 \%)$ foram identificados como Staphylococcus coagulasenegativas e $25(27,2 \%)$ como Staphylococcus coagulasepositivas. A análise de similaridade mostrou uma grande heterogeneidade entre as cepas, entretanto foram isoladas algumas cepas com $100 \%$ de similaridade. Resistência a oxacilina foi encontrada em 39 (42\%) cepas. Duas cepas de estafilococos coagulase-negativos mostraram-se resistentes a vancomicina. Onze cepas (12\%) de estafilococos foram consideradas multirresistentes. Medidas de desinfecção das mãos de pessoal e dos leitos hospitalares e a racionalização do uso indiscriminado de antibióticos podem contribuir para a queda da transmissão de patógenos e diminuição da pressão de seleção, e conseqüentemente diminuindo a freqüência e letalidade das infecções nosocomiais.

Palavras-chaves: Similaridade, RAPD-PCR, multirresistência, Staphylococcus.

\section{REFERENCES}

1. Albrich, W.C.; Harbarth, S. (2008). Health-care workers: Source, vector, or victim of MRSA? Lancet. Infect. Dis., 8, 289.

2. Beretta, A.L.R.Z.; Trabasso, P.; Stucchi, R.B.; Moretti, M.L. (2004). Use of molecular epidemiology to monitor the nosocomial dissemination of methicillin-resistant Staphylococcus aureus in a University Hospital from 1991 to 2001. Braz. J. Méd. Biol. Res., 37, 1345-1531.

3. Burd, M.; Humprheys, H.; Glynn, G.; Mitchell, E.; McDonald, P.; Jonhson, H.; McDonnell, B.; Doyle, D.; Rossney, A. (2003). Control and prevention of methicillin-resistant Staphylococcus aureus in hospitals in Ireland: North-south study of MRSA in Ireland, 1999. $J$. Hosp. Infection., 3, 297-303.

4. Casey, A.L.; Worthington, T.; Caddick, J.M.; Hilton, A.C.; Lambert, P.A. and Elliott, T.S.J. (2006) RAPD for the typing of coagulase- 
negative staphylococci implicated in catheter-related bloodstream infection. J. Infect., 52, 282-289.

5. Casey, A.L.; Worthington, T.; Caddick, J.M.; Hilton, A.C.; Lambert, P.A.; Elliott, T.S.J. (2007). RAPD for the typing of Staphylococcus aureus implicated in nosocomial infection. J. Hosp. Infect., 66, 192-193.

6. Clinical and Laboratory Standards Institute/NCCLS. (2005). Performance standards for antimicrobial susceptibility testing. Document M100-S15. CLSI, Wayne, PA.

7. Creamer, E.; Humphreys, H. (2008). The contribution of beds to healthcare-associated: the importance of adequate decontamination. J. Hosp. Infect., 69, 8-23.

8. Del'Alamo, L.; Huband, M.D. (1999). Antimicrobial susceptibility of coagulase-negative staphylococci and characterization of isolates with reduced susceptibility to glycopeptides. Diagn. Microbiol. Infect. Dis., 34, 185-191.

9. French, G.L.; Otter, J.A.; Shannon, K.P.; Adams, N.M.T.; Watling, D.; Parks, M.J. (2004). Tackling contamination of the hospital environment by methicillin-resistant Staphylococcus aureus (MRSA): a comparison between conventional terminal cleaning and hydrogen peroxide vapour decontamination. J. Hosp. Infect, 57, 31-37.

10. Girou, E.; Legrand, P.; Soing-Altrach, S.; Lemire, A.; Poulain, C.; Allaire, A.; Tkoub-Scheirlinck, L.; Chai, S.H.T.; Dupeyron, C.; Loche, C.M. (2006). Association Between Hand Hygiene Compliance and Methicillin-Resistant Staphylococcus aureus Prevalence in a French Rehabilitation Hospital. Hosp. Epidemiol., 27, 1128-1130.

11. Guerin, F.; Buu-Hoi, A.; Mainardi, J.L.; Kac, G.; Colardelle, N.; Sabine Vaupré, S.; Gutmann, L.; Podglajen, L. (2000). Outbreak of methicillin resistant Staphylococcus aureus with reduced susceptibility to glycopeptides in a Parisian hospital. J. Clin. Microbiol., 38 (8), 2985-2988.

12. Hiramatsu, K.; Mamizuka, E.M. (2001). Isolation in Brazil of nosocomial Staphylococcus aureus with reduced susceptibility to vancomycin. Infect. Control. Hosp. Epidemiol., 22, 443-448.

13. Hiramatsu, K.; Katayama, Y.; Yuzawa, H.; Ito, T. (2002). Molecular genetics of methicillin-resistant Staphylococcus aureus. Int. J. Med. Microbiol., 292, 67-74.

14. Kawamura, Y.; Hou, X.G.; Sultana, F.; Hirose, F.; Miyake, M.; Shu, S.E.; Ezaki, T. (1998). Distribution of Staphylococcus species among human clinical specimens and emended description of Staphylococcus caprae. J. Clin. Microbiol., 36, 2038-2042.

15. Kloss, W.E. (1997). Taxonomy and systematies of staphylococci indigenous to humans: the staphylococci in human disease. New York: Churchill Livingstone, p. 113-138.

16. Koneman, E.W.; Allen, S.D.; Janda, W.M.; Schreckenberger, P.C.; Winn J.R; W.C. (2001). Diagnóstico Microbiológico. Texto e Atlas Colorido. MEDSI, 5 ed. Rio de Janeiro, Brasil, p. 1465.

17. Lowy, F.D. (1998). Staphylococcus aureus infections. N. Engl. J. Med., 339, 520-532.

18. MacDonald, A.; Dinah, F.; MacKenzie, D.; Wilson, A. (2004). Performance feedback of hand hygiene, using alcohol gel as the skin decontaminant, reduces the number of inpatients newly affected by MRSA and antibiotic costs. J. Hosp. Infect., 56, 56-63.

19. Mamizuka, E.M.; Oliveira, G.A. (2000). Isolamento de cepas de Staphylococcus aureus com sensibilidade reduzida a vancomicina em hospital brasileiro. Pharm. Bras., 6, 6-7.

20. Marchese, A.; Balistreri, G.; Torroli, E.; Schito, G.C. (2000). Heterogeneous vancomycin resistance in methicillin- resistant
Staphylococcus aureus strains isolated in a large Italian hospital. $J$ Clin. Microbiol., 38, 866-869.

21. Martins A.; Cunha, M.L.R.S. (2007). Methicillin-resistance in Staphylococcus aureus and coagulase-negative staphylococci: Epidemiological and molecular aspects. Microbiol. Immunol., 51, 787-795.

22. Melo, G.B.; Melo, M.C.; Gama, A.P.; Carvalho, K.S.; Jesus T.C.; Bonetti, A.M.; Filho, P.P.G. (2005). Analysis of the genetic diversity of vancomycin-resistant Staphylococcus aureus. Braz. J. Microbiol., 36, 126-130.

23. Michelim, L.; Michele Lahude, M.; Araújo, P.R.; Giovanaz, D.S.H.; Müller, G.; Delamare, A.P.L.; Costa, S.O.P.; Echeverrigaray, S. (2005). Pathogenicity factors and antimicrobial resistance of Staphylococcus epidermidis associated with nosocomial infections occurring in intensive care units. Braz. J. Microbiol., 36, 17-23.

24. National Committee for Clinical Laboratory Standards. (2003). Methods for dilution antimicrobial susceptibility tests for bacteria that grow aerobically. Approved standards. Document M7-A6. NCCLS, Wayne, PA.

25. National Committee for Clinical Laboratory Standards. (2003). Performance standards for antimicrobial disk susceptibility tests. Approved standards. Document M2-A8. NCCLS, Wayne, PA.

26. Oliveira, G.A.; Dell'Aquila, A.M.; Masiero, R.L.; Levy, C.E.; Gomes, M.S.; Cui, L.; Hiramatsu, K.; Mamizuka, E.M. (2001). Isolation in Brazil of nosocomial Staphylococcus aureus with reduced susceptibility to vancomycin. Infect. Control Hosp. Epidemiol., 22, 443-448.

27. Rello, J.; Rue, M.; Jubert, P. (1997). Survival in patients with nosocomial pneumonia: impact of the severity of illness and the etiologic agent. Crit. Care Med., 25, 1862-1867.

28. Ricardo, S.B. (2004). Emergência de S. aureus Meticilina-Resistente (MRSA) na Comunidade. Prática Hospitalar, 34, 131-134.

29. Santos, O.H.L.R. (1999). Perfil de sensibilidade do S. aureus e $S$. epidermidis no Hospital Municipal Souza Aguiar, $1^{\circ}$ semestre de 1998. Rev. Soc. Bras. Med. Trop., 32 (supl 1), 423.

30. Senna, J.P.M.; Sukiennik, T.C.T.; Gottardo I.R.; DeDalid, S.M.M.; Santos, D.S. (1996). Identificação dos genes mecA e femA em amostras de $S$. aureus resistentes à meticilina/oxacilina de pacientes da irmandade Santa casa de Misericórdia de Porto Alegre. Congresso Brasileiro de Controle de Infecção Hospitalar, Rio de Janeiro, Brasil, p. 85.

31. Shlaes, D.M.; Gerding, D.N.; John, J.F.Jr. et al. (1997). Society for Healthcare Epidemiology of America and Infectious Diseases Society of America Joint Committee on the Prevention of Antimicrobial Resistance: Guidelines for the Prevention of Antimicrobial Resistance in Hospitals. Clin. Infec. Dis., 25, 584-599.

32. Singh, A.; Goering, R.V.; Simjee, S.; Foley, S.L.; Zervos, M.Z. (2006). Application of molecular techniques to the study of hospital infection. Cl. Microbiol. Reviews. 19, 512-530.

33. Tenover, F.C.; Lancaster, M.V.; Hill, B.C.; Steward, C.D.; Stocker, S.A.; Hancock, G.A.; O‘Hara, C.M.; Clark, N.C.; Hiramatsu, K. (1998). Characterization of Staphylococci with reduced susceptibilities to vancomycin and other glycopeptides. J. Clin. Microbiol., 36, 4, 10201027.

34. Wong, S.S.; Ng, T.K.; Yam, W.C.; Tsang, D.N.; Woo, P.C.; Fung, S.K.; Yuen, K.Y. (2000). Bacteremia due to Staphylococcus aureus with reduced susceptibility vancomycin. Diag. Microbiol. Infect. Dis., 36, 261-268. 